\title{
ANALISIS JANUARY EFFECT DITINJAU DARI ABNORMAL RETURN DAN TRADING VOLUME ACTIVITY PADA KELOMPOK SAHAM LQ 45 DI BURSA EFEK INDONESIA PERIODE 2010-2016
}

\author{
Rohmi Saofiah ${ }^{1}$, Zainal Abidin², G.A. Sri Oktaryani ${ }^{3}$, \\ ${ }^{1}$ Alumni Jurusan Manajemen Fakultas Ekonomi dan Bisnis Universitas Mataram, rohmisaofiah@gmail.com \\ ${ }^{2}$ Fakultas Ekonomi dan Bisnis Universitas Mataram, abidin260860@gmail.com \\ ${ }^{3}$ Fakultas Ekonomi dan Bisnis Universitas Mataram, oktaryani@gmail.com
}

\begin{abstract}
ABSTRAK
Penelitian ini bertujuan untuk melihat fenomena January effect pada kelompok saham LQ45 yang terdapat di Bursa Efek Indonesia. January effect adalah anomaly yang menyajikan abnormal return saham tertinggi terjadi dibulan Januari jika dibandingkan dengan sebelas bulan lainnya. Proksi yang digunakan adalah abnormal return dan trading volume activity. Penelitian ini dilakukan pada 20 perusahaan yang secara statis antara tahun 2010 sampai tahun 2016 berada dalam kelompok indeks LQ45 di Bursa Efek Indonesia. Metode penentuan sampel yang digunakan adalah purposive sampling. Alat analisis yang digunakan dalam penelitian ini uji beda Paired sample t-test dan uji Wilcoxon Sign Test. Hasil analisis penelitian menunjukkan bahwa dari sisi abnormal return secara keseluruhan tidak terdapat fenomena January effect pada kelompok saham LQ45 di Bursa Efek Indonesia, begitu juga dari sisi trading volume activity, January effect tidak terjadi pada kelompok saham LQ45di Bursa Efek Indonesia.
\end{abstract}

Katakunci: January effect, abnormal return, trading volume activity

\begin{abstract}
This research aims to look at the January effect phenomenon in the LQ45 stock group found on the Indonesia Stock Exchange. The January effect is the anomaly that presents the highest stock abnormal return in January when compared to the other eleven months. Proxies used in 20 static companies between 2010 and 2016 are in the LQ45 index group on the Indonesia Stock Exchange. The sampling method used was purposive sampling. The analytical tool used in this study is a different test Paired sample t-test and Wilcoxon Sign Test. The results of the analysis showed that from the abnormal return side from 2010 to 2016 there was no January effect phenomenon in the LQ45 stock group on the Indonesia Stock Exchange which was calculated by Paired sample t-test, as well as from the trading volume activity, January effect did not occur from from 2010 to 2016 in the LQ45 stock group on the Indonesia Stock Exchange which was calculated by the Wilcoxon Sign Test.
\end{abstract}

Keywords: January effect, abnormal return, trading volume activity

\section{PENDAHULUAN}

Pasar modal secara umum merupakan tempat bertemunya pihak yang membutuhkan dana (emiten) dengan pihak yang kelebihan dana (investor). Pasar modal dapat membantu perusahaan dalam menghimpun dana untuk memperkuat permodalan perusahaan serta membantu pihak lainnya dalam menginvetasikan dana dan belajar cara berinvestasi untuk kebutuhan di masa yang akan datang. Hal tersebut tentunya sangat menarik minat para investor terutama jika emiten menyediakan segala informasinya dengan sangat jelas sesuai yang dipaparkan oleh Teori Sinyal menjelaskan bagaimana informasi tersebut sangat berpengaruh terhadap harga saham suatu perusahaan dan dapat membantu para investor untuk mengambil keputusan investasi guna memperoleh return yang diharapkan. 
Return merupakan hasil yang diharapkan investor atas dana yang telah diinvestasikannya. Return dapat berupa return realisasi yang sudah terjadi dan return ekspektasi yang belum terjadi tetapi yang diharapkan akan terjadi dimasa yang akan datang. Segala informasi yang tersedia akan mencerminkan pergerakan tingkat return sesungguhnya yang akan diterima oleh investor serta aktivitas pergerakan harga saham jika pasar dalam keadaan efisien.

Fama (1970) dalam Maliasari (2013) mengklasifikasikan pasar efisien kedalam tiga bentuk yaitu: : 1) pasar efisien bentuk lemah (weak form), 2) pasar efisien bentuk setengah kuat (semi strong form), 3) pasar efisien bentuk kuat (strong form). Pada pasar yang efisien, pasar akan cepat bereaksi terhadap informasi baru yang masuk sehingga pasar cenderung lebih cepat pula mencapai harga keseimbangan yang baru. Saat pasar saham bereaksi atas hal yang tidak termasuk ke dalam konsep pasar efisien, hal itulah yang disebut sebagai anomlai atau gangguan.

Anomali adalah kejadian atau peristiwa yang tidak dapat diantisipasi dan menawarkan investor peluang untuk memperoleh abnormal return. Ada beberapa bentuk anomali musiman yang menawarkan investor peluang untuk memperoleh abnormal return di saat-saat tertentu, salah satu bukti penyimpangan yang berpola musiman tersebut dapat terjadi ketika pergantian tahuan yaitu January Effect. January effect merupakan bagian dari anomali musiman dalam tahun atau biasa disebut month of the year effect yang merupakan kecenderungan terjadinya peningkatan return khususnya pada pekan pertama bulan Januari (Andreas dan Daswan, 2011). Masyarakat atau investor cenderung membutuhkan dana yang besar di akhir tahun untuk perayaan natal dan tahun baru sehingga akan menjual saham yang dimilikinya untuk memperoleh dana. Sehingga karakteristik dari Januari effect adalah peningkatan pembelian surat berharga sebelum akhir tahun dengan harga yang rendah, dan menjualnya pada Januari untuk menghasilkan laba dari perbedaan harga (Rahayu, 2015). Adanya peristiwa January effect ini dapat dimanfaatkan sebagai salah satu bentuk dari anomali musiman yang memberikan kesempatan kepada investor untuk memperoleh abnormal return.

Abnormal return merupakan return yang diperoleh dari selisih antara expected return dengan realized return, atau selisih antara return yang diharapkan dengan return yang didapatkan sesungguhnya. Abnormal return dapat berbentuk keuntungan atau bernilai positif jika selisih return yang didapatkan lebih besar dari return yang diharapkan atau dapat juga bernilai negatif jika return yang diperoleh lebih sedikit dari return yang diharapkan (Bodie el al. 2011:383). Selain menggunakan abnormal return, January Effect dapat pula ditunjukkan menggunakan besarnya volume perdagangan saham yang dapat diukur dengan TradingVolume Activity (TVA) pada sekitar kejadian, hal tersebut membantu melihat fenomena dari sisi aktifnya transaksi yang terjadi. JanuaryEffect akan membuat pasar begitu ramai di bulan Januari.

Objek dalam penelitian ini adalah perusahaan yang berada pada indeks 45 saham yang memiliki tingkat likuiditas tertinggi di Bursa Efek Indonesia atau indeks LQ 45 dan merupakan salah satu indikator indeks saham di BEI yang dapat dijadikan acuan sebagai bahan untuk menilai kinerja perdagangan saham. Dari sekian banyak saham yang terdaftar di BEI, saham yang berada pada indeks LQ 45 ini merupakan saham yang paling banyak diminati oleh para investor.

Beberapa penelitian sebelumnya menunjukkan keberagamannya dalam hasil, diantaranya oleh Fitriyani dan Sari (2013) mencoba melakukan penelitian untuk membuktikan secara empiris apakah January effect terjadi di BEI selama periode 2009-2011, kemudian oleh Wulandari (2014) yang ingin membuktikan secara 
empiris apakah January effect terjadi pada saham LQ 45 yang listing di BEI periode 2009-2013. Hasil yang diperoleh dari kedua penelitian tersebut bahwa nilai signifikan menunjukkan beda abnormal return saham bulanan dalam transaksi perdagangan bulan Januari dengan bulan lainnya. Hasil yang berbeda ditunjukkanoleh Pertiwi dan Isynuwardana (2015) yang ingin melihat fenomena January Effect pada Perusahaan LQ 45di Bursa Efek Indonesia selama periode 2009 - 2013. Hasil dari penelitian Pertiwi dan Isynuwadana tidak membuktikan bahwa anomali January effect terjadi di perusahaan yang terdaftar dalam Indeks LQ 45 periode 2009-2013 karena memang terjadi perbedaan return bulan Januari dengan bulan lainnya tetapi return bulan Januari tidak menunjukkan return yang selalu positif dan nilai return bulan Januari tidak selalu lebih tinggi jika dibandingkan dengan bulan lainnya.

\section{Perumusan Masalah}

Berdasarkan uraian di atas, dapat ditarik rumusan masalah sebagai berikut "apakah terdapat perbedaan return dan trading volume activity antara bulan Januari dengan sebelas bulan lainyapada kelompok saham LQ 45 selama periode 2010-2016?”

\section{Tujuan Penelitian}

Berdasarkan rumusan masalah di atas, maka tujuan penelitian ini yaitu untuk mengujiapakah terdapat perbedaan abnormal return dan trading volume activity antara bulan Januari dengan sebelas bulan lainyapada kelompok saham LQ 45 selama periode 2010-2016.

\section{Abnormal Return}

\section{TINJAUAN LITERATUR}

Abnormal return terjadi karena adanya informasi baru atau peristiwa baru yang merubah nilai perusahaan dan direaksi oleh investor dalam bentuk kenaikan atau penurunan harga saham (volatilitas) (Hartono, 2010:537). Abnormal return atau excess return merupakan kelebihan dari return yang sesungguhnya terjadi terhadap return normal atau perbandingan dari return realisasi dengan return ekpektasi.

\section{Trading Volume Activity}

Volume perdagangan saham merupakan rasio antara jumlah lembar saham yang diperdagangkan pada waktu tertentu terhadap jumlah saham yang beredar pada waktu tertentu (Husnan, 2009:63). Volume perdagangan saham adalah salah satu indikator yang digunakan untuk melihat reaksi pasar terhadap kejadian atau informasi yang berkaitan dengan suatu saham. Perubahan volume perdagangan diukur dengan aktivitas volume perdagangan saham yang diukur dengan Trading Volume Activity (TVA). TVA merupakan perbandingan antara jumlah saham yang diperdagangkan pada waktu tertentu dengan jumlah saham perusahaan yang beredar pada periode tertentu.

\section{Penelitan Terdahulu}

Octavianti (2010) melakukan penelitian tentang January effect January effect di masing-masing sektor pada 9 sektor indeks saham sektoral di Bursa Efek Indonesia periode 2001-2008, yaitu sektor pertanian, pertambangan, industri dasar, aneka industri, konsumsi, properti, infrastruktur, keuangan, perdagangan dan jasa. Hasil pengujian hipotesis menunjukkan adanya return pasar tertinggi pada bulan Januari yang mempunyai nilai positif. Dengan hasil tersebut maka dapat diketahui bahwa fenomena 
January effect terjadi selama periode penelitian ditandai dengan adanya return pasar pada bulan Januari lebih tinggi dan signifikan pada beberapa sektor dalam indeks sektoral.

Astuti dan Legowo (2012) melakukan penelitian terhadap beda abnormal return saham bulanan di Bursa Efek Jakarta selama tahun 2004-2006 yang dilakukan dengan One Way Analisis of Variance (ANOVA) menunjukkan bahwa beda rata-rata abnormal return saham bulanan dalam transaksi perdagangan signifikan dengan kata lain menolak Ho. Dapat disimpulkan bahwa January effect terjadi di Bursa Efek Jakarta. Wulandari (2014) melakukan penelitian tentang January effect dengan menguji beda abnormal return saham bulanan perusahaan LQ 45 di Bursa Efek Indonesia selama tahun 20092013 yang diperoleh dari analisis varian satu arah (one wayANOVA), didapatkan nilai signifikan menunjukkan bahwa beda abnormal return saham bulanan dalam transaksi perdagangan bulan Januari dengan bulan lainnya. Jadi, penelitian ini telah membuktikan secara empiris bahwa terjadi January effect pada perusahaan LQ 45 di Bursa Efek Indonesia pada periode 2009-2013.

Andreas dan Daswan (2011) melakukan penelitian tentang January effect yang menunjukan bahwa abnormal return tidak signifikan pada level 5 persen. Sehingga dapat disimpulkan bahwa tidak terdapat fenomena January effect pada perusahaan yang termasuk dalam LQ 45 pada periode penelitian karena hasil yang tidak menunjukkan abnormal return yang selalu positif dan nilai abnormal return bulan Januari tidak selalu lebih tinggi jika dibandingkan dengan bulan lainnya. Marliasari (2013) melakukan penelitian tentang "Pengaruh Januarry Effect dan Rogalski Effect terhadap Abnormal return Saham dan Trading Volume Activity. Alat analisis yang digunakan adalah kruskall-wallis dengan hasil penelitian membuktikan bahwa fenomena January Effect tidak terjadi pada indeks LQ45 BEI periode 2011. Sehingga berdampak pula terhadap Abnormal Return bulan Januari. Sedangkan pada periode 2012 terbukti terdapat pengaruh yang signifikan pada Abnormal Return, sehingga mengindikasikan bahwa terjadi January Effect pada indeks LQ 45 BEI periode 2012. Namun keberadaan January Effect baik periode 2011 maupun 2012 tidak terbukti berpengaruh lebih terhadap Trading Volume Activity atau volume pedagangan saham, yang itu artinya tetap ada perbedaan tetapi tidak signifikan sehingga tidak mengindikasikan adanya fenomena January Effect.

\section{Kerangka Konseptual dan Pengembangan Hipotesis}

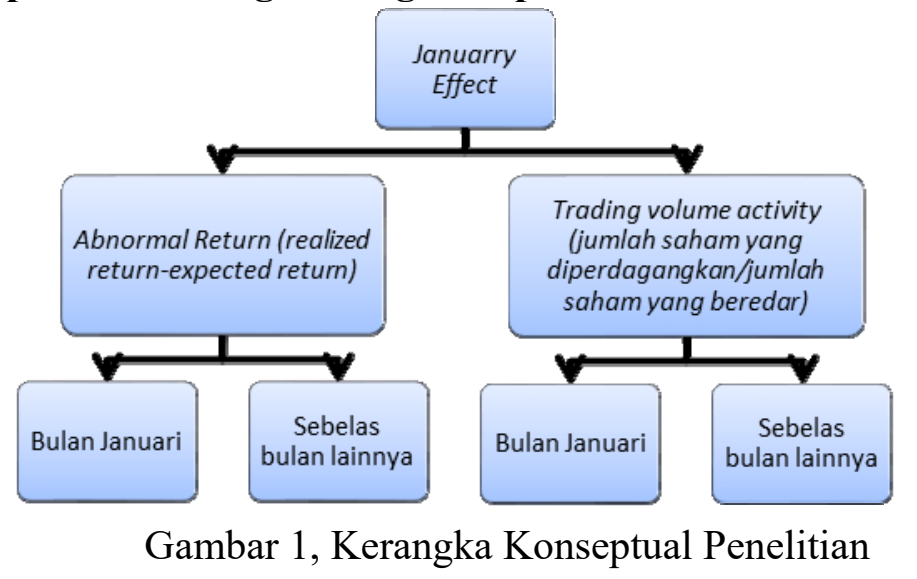


January effect sebagai bentuk anomali pasar dimana kondisi pasar dalam keadaan yang tidak efisien yang memungkinkan investor untuk mendapatkan abnormal return. Abnormal return tersebut merupakan returnyang memiliki nilai positif karena nilai return yang didapatkan melebihi return yang diharapkan. Selain menggunakan return, penelitian ini melihat volume perdagangan saham yang terjadi pada bulan Januari, dimana volume perdagangan saham adalah salah satu indikator yang digunakan untuk melihat reaksi pasar terhadap kejadian atau informasi yang berkaitan dengan suatu saham.

Berdasarkan penjelasan dari pengembangan hipotesis yang sudah dijelaskan sebelumnya maka dapat ditarik hipotesis untuk penelitian ini sebagai berikut:

H1: Diduga terdapat perbedaan signifikan dan tidak signifikan pada beberapa tahun dilihat dari sisi abnormal return dan trading volume activity antara bulan Januari dengan sebelas bulan lainnya pada perusahaan LQ 45 di Bursa Efek Indonesia.

\section{METODE PENELITIAN}

Jenis penelitian yang digunakan dalam penelitian ini adalah komparatif yaitu suatu penelitian yang membandingkan suatu variabel atau lebih pada satu atau lebih sampel yang berbeda, atau pada waktu yang berbeda (Sugiyono, 2012:54). Peristiwa yang diuji pada penelitian ini adalah melihat adanya reaksi pasar modal berupa perbedaan abnormal return yang diperoleh pemegang saham di bulan Januari dengan bulan-bulan lainnya dan perbedaan volume perdagangan akibat dari adanya January effect pada kelompok saham Indeks LQ 45 di Bursa Efek Indonesia periode pengamatan 2010-2016.

Populasi dalam penelitian ini adalah seluruh perusahaan yang termasuk dalam kategori indeks LQ45 periode 2010-2016 yaitu 45 saham perusahaan. Teknik sampling yang digunakan dalam penelitian ini adalah purposive sampling. Menurut Sugiyono (2012:122) purposive sampling adalah teknik penentuan sampel dengan pertimbangan tertentu. Kriteria yang ditetapkan dalam penelitian ini yaitu perusahaan yang selalu masuk dalam indeks LQ 45 di tahun 2010-2016. Sehingga, berdasarkan pertimbangan tersebut maka terpilih 20 perusahaan kategori LQ45 yang menjadi sampel dalam penelitian ini yaitu:

Tabel 1. Sampel Penelitian

\begin{tabular}{|c|c|c|}
\hline NOMOR & $\begin{array}{c}\text { KODE } \\
\text { SAHAM }\end{array}$ & NAMA EMITEN \\
\hline 1 & AALI & Astra Agro Lestari Tbk \\
\hline 2 & ADRO & Adaro Energy Tbk \\
\hline 3 & ASII & Astra International Tbk \\
\hline 4 & BBCA & Bank Central Asia Tbk \\
\hline 5 & BBNI & Bank Negara Indonesia Tbk \\
\hline 6 & BBRI & Bank Rakyat Indonesia (Persero) Tbk \\
\hline 7 & BMRI & Bank Mandiri (Persero) Tbk \\
\hline 8 & GGRM & Gudang Garam Tbk \\
\hline 9 & INDF & Indofood Sukses Makmur Tbk \\
\hline 10 & INTP & Indocement Tunggal Prakarsa Tbk \\
\hline 11 & JSMR & Jasa Marga (Persero) tbk \\
\hline 12 & KLBF & Kalbe Farma Tbk \\
\hline
\end{tabular}




\begin{tabular}{|l|l|l|}
\hline NOMOR & \multicolumn{1}{|c|}{$\begin{array}{c}\text { KODE } \\
\text { SAHAM }\end{array}$} & \multicolumn{1}{c|}{ NAMA EMITEN } \\
\hline 13 & LPKR & Lippo Karawaci Tbk \\
\hline 14 & LSIP & London Sumatera Plantation Tbk \\
\hline 15 & PGAS & Perusahaan Gas Negara (Persero) Tbk \\
\hline 16 & PTBA & Tambang Batu Bara Bukit Asam (Persero) Tbk \\
\hline 17 & SMGR & Semen Gresik (Persero) Tbk \\
\hline 18 & TLKM & Telekomunikasi Indonesia (Persero) Tbk \\
\hline 19 & UNTR & United Tractor Tbk \\
\hline 20 & UNVR & Unilever Indonesia Tbk \\
\hline
\end{tabular}

Sumber: data IDX, diolah

\section{METODE ANALISIS DATA}

Prosedur pengumpulan data yang digunakan dalam penelitian ini adalah nonparticipant observation, yaitu teknik pengumpulan data dengan observasi atau pengamatan dimana peneliti tidak terlibat secra langsung dan hanya sebagai pengamat inependen, (Sugiyono, 2012:204). Adapun pengujian dan urutan prosedur analisis data yang akan dilakukan sebagai berikut:

\section{Menghitung return sesungguhnya (realized return)}

Keterangan:

$$
\text { Rit }=\frac{\text { Pit }_{- \text {Pit }_{-1}}}{\text { Pit }_{-1}}
$$

Rit = return saham masing-masing perusahaan LQ 45

Pit= harga saham penutupan masing-masing perusahaan LQ 45

$\mathrm{Pit}_{-1} \quad$ = harga saham penutupan masing-masing perusahaan LQ 45 pada periode $\mathrm{t}_{-1}$ (Hartono, 2010:199)

2. Menghitung return ekspektasi dengan menggunakan rumus:

Estimasi expected return menurut Brown dan Warner (1985) dalam Hartono (2008:550) menggunakan model sebagai berikut:

$$
\text { (E) } R \mathrm{tt}=\mathrm{RM} \mathrm{t}=\frac{\text { Indeks LQ 45t }- \text { Indeks LQ 45t } \mathrm{t}_{-1}}{\text { Indeks LQ } 45 \mathrm{t}_{-\mathrm{l}}}
$$

Dimana:

(E) Rit $\quad=$ Expected Return bulanan Indeks LQ 45

RMt = Return Market bulanan Indeks LQ45

Indeks LQ45 $\mathrm{t}=$ Indeks pasar bulan ke $\mathrm{t}$

Indeks LQ45-1= Indeks pasar bulan ke $\mathrm{t}-1$

\section{Menghitung Abnormal return Bulanan}

$$
\text { ARit }=\text { Rit }-(\text { E) Rit }
$$

Dimana:

ARit = Abnormal return bulanan perusahaan LQ 45

Rit $=$ Return saham masing-masing perusahaan LQ 45

(E)Rit $=$ Expected Return perusahaan LQ 45

(Hartono, 2016:648)

4. Menghitung Trading Volume Activity (TVA)

132 | Analisis January Effect Ditinjau dari Abnormal Return dan Trading... | 
(Husnan, 2009:63)

$$
\text { TVA }=\frac{\text { Jumlah saham yang dipendaganglan }}{\text { funnlah saham yang bevedar }}
$$

5. Menguji Signifikansi

1. Uji Normalitas

Uji normalitas data dilakukan dengan tujuan untuk mengetahui kenormalan distribusi sebaran skor variabel (Ghozali, 2006:27). Untuk mengetahui normalitas dapat digunakan skor signifikansi yang ada pada hasil penghitungan Kolmogorovsmirnov.

\section{Uji Beda t-test (Paired Sample t-test)}

Uji beda Paired sample t-test (uji t untuk dua sampel yang berpasangan)yaitu alat analisis yang bertujuan untuk mengetahui ada tidaknya January effect pada saham-saham di Indeks LQ 45 dengan melakukan perbandingan antara rata-rata abnormal return dan jumlah volume perdagangan bulan Januari dengan sebelas bulan lainnya apakah cukup signifikan ataukah tidak perbedaan tersebut selama periode penelitian. Jenis data yang digunakan harus berskala rasio atau interval,

3. Uji Wilcoxon Sign Test

Uji jenjang bertanda Wilcoxon digunakan untuk menganalisis hasil-hassil pengamatan yang berpasangan dari dua data apakah berbeda atau tidak, antara sebelum dan sesudah perlakuan tertentu. Uji Wilcoxon ini adalah tes yang paling berguna untu ilmuan social, karena dapat membuat penilaian tentang "lebih besar dari" antara dua penampilan dalam masing-masing pasangan, dan juga dapat membuat penilaian antara dua skor berbeda yang timbul dari setiap dua pasang.

\section{HASIL PENELITIAN}

\section{Analisis Data Abnormal Return (AR)}

\section{a. Hasil Perhitungan dan Statistik Deskriptif AR}

Berikut hasil data rata-rata abnormal return bulanan yang diperoleh dari selisih antara realized return dengan expected return seluruh perusahaan LQ45 yang telah memenuhi kriteria penelitian dari tahun 2010 hingga 2016 dan telah diolah;

Tabel 2. Tabel Rata-rata Abnormal Return Perusahaan Indeks LQ 45 Periode 2010-2016 (dalam persentase)

\begin{tabular}{|l|c|c|c|c|c|c|c|}
\hline \multicolumn{1}{|c|}{ BULAN } & $\mathbf{2 0 1 0}$ & $\mathbf{2 0 1 1}$ & $\mathbf{2 0 1 2}$ & $\mathbf{2 0 1 3}$ & $\mathbf{2 0 1 4}$ & $\mathbf{2 0 1 5}$ & $\mathbf{2 0 1 6}$ \\
\hline JANUARI & -0.01312 & -0.08289 & -0.01812 & -0.00500 & -0.03318 & -0.02002 & 0.01325 \\
\hline FEBRUARI & 0.02432 & 0.01362 & 0.02908 & 0.01762 & 0.01993 & -0.00725 & -0.02370 \\
\hline MARET & 0.02588 & 0.03482 & 0.05988 & -0.00242 & -0.00278 & -0.02926 & 0.01013 \\
\hline APRIL & -0.00560 & -0.01004 & -0.04158 & -0.01527 & -0.00135 & -0.06484 & 0.00315 \\
\hline MEI & 0.00263 & -0.01495 & -0.04567 & -0.03148 & -0.01441 & 0.08401 & -0.00329 \\
\hline JUNI & 0.01288 & 0.02478 & 0.02700 & 0.06338 & 0.01637 & -0.01910 & 0.04646 \\
\hline JULI & 0.02717 & -0.00312 & 0.02105 & -0.07751 & 0.00954 & -0.03179 & 0.01039 \\
\hline AGUSTUS & -0.01348 & -0.03382 & -0.05498 & 0.01763 & -0.02759 & 0.00411 & -0.00658 \\
\hline SEPTEMBER & 0.04002 & -0.01166 & 0.04076 & -0.01636 & -0.01443 & -0.00442 & -0.00653 \\
\hline OKTOBER & -0.01391 & 0.09900 & -0.06848 & 0.03077 & 0.04381 & 0.02697 & 0.01983 \\
\hline
\end{tabular}




\begin{tabular}{|l|c|c|c|c|c|c|c|}
\hline \multicolumn{1}{|c|}{ BULAN } & $\mathbf{2 0 1 0}$ & $\mathbf{2 0 1 1}$ & $\mathbf{2 0 1 2}$ & $\mathbf{2 0 1 3}$ & $\mathbf{2 0 1 4}$ & $\mathbf{2 0 1 5}$ & $\mathbf{2 0 1 6}$ \\
\hline NOVEMBER & -0.03841 & -0.05197 & -0.03267 & 0.00267 & -0.00080 & -0.03921 & -0.00244 \\
\hline DESEMBER & 0.05949 & 0.02593 & 0.05772 & 0.06772 & -0.02085 & 0.02894 & 0.04461 \\
\hline Tertinggi & $\mathbf{0 . 0 5 9 4 9}$ & $\mathbf{0 . 0 9 9 0 0}$ & $\mathbf{0 . 0 5 9 8 8}$ & $\mathbf{0 . 0 6 7 7 2}$ & $\mathbf{0 . 0 4 3 8 1}$ & $\mathbf{0 . 0 8 4 0 1}$ & $\mathbf{0 . 0 4 6 4 6}$ \\
\hline Terendah & $\mathbf{- 0 . 0 3 8 4 1}$ & $\mathbf{- 0 . 0 8 2 8 9}$ & $\mathbf{- 0 . 0 6 8 4 8}$ & $\mathbf{- 0 . 0 7 7 5 1}$ & $\mathbf{- 0 . 0 3 3 1 8}$ & $\mathbf{- 0 . 0 6 4 8 4}$ & $\mathbf{- 0 . 0 2 3 7 0}$ \\
\hline
\end{tabular}

Sumber: Data sekunder diolah

Berdasarkan tabel tersebut dapat disimpulkan bulan Januari tidak selalu menempati posisi dengan nilai abnormal return tertinggi setiap tahunnya, melainkan acak. Nilai tertinggi tersebut sering kali ditemui pada bulan Desember yang dimana menempati posisi tertinggi sebanyak tiga kali yaitu di tahun 2010, 2013 dan 2016. Adapun bulan yang kerap kali didapati pada posisi abnormal return yang terendah yakni bulan Januari dan Oktober, dimana Januari dua kali berada pada posisi nilai terendah yaitu di tahun 2011 dan 2014 sedangkan bulan Oktober terdapat di tahun 2010 dan 2012.

\section{b. Uji Normalitas Data}

Tabel 3. Hasil Uji Normalitas AR (Abnormal Return)

Tests of Normality

\begin{tabular}{|l|r|r|r|r|r|r|}
\hline & \multicolumn{3}{|c|}{ Kolmogorov-Smirnov $^{\mathrm{a}}$} & \multicolumn{3}{c|}{ Shapiro-Wilk } \\
\cline { 2 - 7 } & Statistic & \multicolumn{1}{|c|}{ Df } & \multicolumn{1}{c|}{ Sig. } & Statistic & \multicolumn{1}{c|}{ Df } & \multicolumn{1}{c|}{ Sig. } \\
\hline Ab_Januari & .108 & 20 & $.200^{*}$ & .968 & 20 & .709 \\
Ab_sebelasbulanlainnya & .101 & 20 & $.200^{*}$ & .962 & 20 & .594 \\
\hline
\end{tabular}

a. Lilliefors Significance Correction

*. This is a lower bound of the true significance.

Sumber: data sekunder output SPSS

Berdasarkan hasil di atas terlihat bahwa nilai signifikan pada tabel KolmogrovSimirnov untuk abnormal return Januari dan Sebelas bulan lainnya adalah 0.200, yang mana lebih besar dari 0.05 , sehingga dapat diteruskan ke dalam analisis selanjutnya yaitu analisis statistik parametrik yang dalam hal ini menggunakan statistik uji paired sample t-test.

\section{c. Uji Hipotesis (Paired sample t-test)}

Tabel 4. Hasil Uji Paired Sample t-test

\begin{tabular}{|l|r|r|r|r|r|r|r|}
\hline & $\begin{array}{l}\text { Ab_Jan10 } \\
\text { Ab_11bln10 }\end{array}$ & $\begin{array}{l}\text { Ab_Jan11 } \\
\text { Ab_11bln1 }\end{array}$ & $\begin{array}{c}\text { Ab_Jan12 } \\
\text { Ab_11bln12 }\end{array}$ & $\begin{array}{l}\text { Ab_Jan13 } \\
\text { Ab_11bln }\end{array}$ & $\begin{array}{l}\text { Ab_Jan14 } \\
\text { Ab_11bln14 }\end{array}$ & $\begin{array}{l}\text { Ab_Jan15 } \\
\text { Ab_11bln15 }\end{array}$ & $\begin{array}{l}\text { Ab_Jan16 } \\
\text { Ab_11bln16 }\end{array}$ \\
\hline $\mathrm{T}$ & -2.119 & -3.462 & -1.121 & -0.731 & -1.175 & -1.044 & 0.261 \\
\hline $\begin{array}{l}\text { Sig. } \\
\left(\begin{array}{l}2- \\
\text { tailed }\end{array}\right.\end{array}$ & 0.048 & 0.003 & 0.276 & 0.474 & 0.254 & & \\
\hline
\end{tabular}

Sumber: data output spss (lampiran)

Pada tabel hasil uji paired sample t-test (lampiran)dari tahun 2010-2016 terdapat hasil yang berbeda antara tahun 2010 dan 2011 yaitu secara berturut-turut nilai signifikansinya 0.048 dan 0.003 yang mana menandakan $\mathrm{P}$ value $<$ dari 0.05 . Terdapat nilai kolom t hitung masing-masing tahun secara berturt-turut -2.119 dan -3.462 , 
kemudian tabel distribusi t dicari pada $\alpha=5 \%$ dengan derajat kebebasan (df) $n-1$ atau 20-1=19. Dengan perbedaan rata-rata (mean diference) sebesar -0.0235 di tahun 2010 dan -0.089297 di tahun 2011, perbedaan berkisar untuk lower sebesar -0.0467 di tahun 2010 dan -0.143285 di tahun 2011 kemudian upper sebesar-0.0003 di tahun 2010 dan 0.035310 di tahun 2011. Pada lima tahun berikutnya, yaitu tahun 2012, 2013, 2014, 2015 dan 2016 terdapat hasil signifikan secara berturut-turut $0.276,0.474,0.254,0.310$, 0.797 dan $\mathrm{P}$ value $>0.05$. Hal tersebut mengindikasikan bahwa Ha diterima atau terdapat perbedaan signifikan dan tidak signifikan pada beberapa tahun dilihat dari sisi abnormal return Januari dan sebelas bulan lainnya pada perusahaan LQ45 di Bursa Efek Indonesia.

2. Analisis Data Trading Volume Activity (TVA)

a. Hasil Perhitungan dan Statistik Deskriptif TVA

Tabel 5. Tabel Rata-rata Trading Volume Activity Perusahaan Indeks LQ 45 Periode 2010-2016 (aktivitas)

\begin{tabular}{|c|c|c|c|c|c|c|c|}
\hline Bulan & 2010 & 2011 & 2012 & 2013 & 2014 & 2015 & 2016 \\
\hline JANUARI & 4.7743E-05 & 7.449E-05 & 4.33013E-05 & 5.0227E-05 & $3.52951 \mathrm{E}-05$ & $3.028 \mathrm{E}-05$ & 2.5747E-05 \\
\hline FEBRUARI & 4.3669E-05 & 5.79959E-05 & $5.49638 \mathrm{E}-05$ & 4.7959E-05 & 3.3012E-05 & $2.634 \mathrm{E}-05$ & 3.0683E-05 \\
\hline MARET & 8.7819E-05 & $6.80555 \mathrm{E}-05$ & 4.32235E-05 & 4.8647E-05 & $3.626 \mathrm{E}-05$ & 3.083E-05 & $3.2416 \mathrm{E}-05$ \\
\hline APRIL & 8.2471E-05 & 5.34233E-05 & $5.60435 \mathrm{E}-05$ & 5.6704E-05 & 3.33797E-05 & 2.733E-05 & 2.9602E-05 \\
\hline MEI & 7.7236E-05 & 4.88915E-05 & $6.166 \mathrm{E}-05$ & $6.3816 \mathrm{E}-05$ & 2.73014E-05 & $2.948 \mathrm{E}-05$ & 2.7318E-05 \\
\hline JUNI & $6.0899 \mathrm{E}-05$ & 4.41209E-05 & 4.69084E-05 & 7.8421E-05 & $2.45025 \mathrm{E}-05$ & 2.398E-05 & $3.205 \mathrm{E}-05$ \\
\hline JULI & $6.471 \mathrm{E}-05$ & $4.59728 \mathrm{E}-05$ & 4.93679E-05 & 8.07E-05 & $2.8296 \mathrm{E}-05$ & $2.298 \mathrm{E}-05$ & $3.4486 \mathrm{E}-05$ \\
\hline AGUSTUS & $6.3766 \mathrm{E}-05$ & $6.26873 \mathrm{E}-05$ & 4.3529E-05 & $3.2475 \mathrm{E}-05$ & $2.59308 \mathrm{E}-05$ & 2.684E-05 & $4.6386 \mathrm{E}-05$ \\
\hline SEPTEMBER & 5.4637E-05 & 5.67012E-05 & 4.07665E-05 & 3.7998E-05 & $2.74676 \mathrm{E}-05$ & $2.763 \mathrm{E}-05$ & 3.6086E-05 \\
\hline OKTOBER & 8.5777E-05 & $5.69698 \mathrm{E}-05$ & 5.1079E-05 & 3.1359E-05 & 3.35959E-05 & 3.49E-05 & 3.3193E-05 \\
\hline NOVEMBER & 9.869E-05 & 3.47879E-05 & 4.3091E-05 & 2.9547E-05 & 2.29839E-05 & 3.011E-05 & 6.13E-05 \\
\hline DESEMBER & $6.9834 \mathrm{E}-05$ & $3.63798 \mathrm{E}-05$ & $4.91821 \mathrm{E}-05$ & $2.4759 \mathrm{E}-05$ & 2.25541E-05 & $2.514 \mathrm{E}-05$ & $2.5622 \mathrm{E}-05$ \\
\hline Tertinggi & $9.869 \mathrm{E}-05$ & 7.449E-05 & 6.166E-05 & 8.07E-05 & $3.626 \mathrm{E}-05$ & 3.49E-05 & 6.13E-05 \\
\hline Terendah & 4.367E-05 & $3.479 \mathrm{E}-05$ & $4.077 \mathrm{E}-05$ & $2.48 \mathrm{E}-05$ & $2.255 \mathrm{E}-05$ & 2.3E-05 & 2.56E-05 \\
\hline
\end{tabular}

Sumber: Data sekunder diola

Bedasarkan hasil tabel data rata-rata trading volume activitybulanan yang diperoleh dari pembagian antara jumlah saham yang diperdagangkan (listed shares) denganjumlah saham yang beredarseluruh perusahaan LQ45 yang telah memenuhi kriteria penelitian dari tahun 2010 hingga 2016 dan telah diolah, sehingga dapat disimpulkan bulan Januari hanya sekali menempati poisi tertinggi yakni di tahun 2011 saja dan tidak pernah menempati posisi dengan nilai trading volume activity tertinggi pada tahun yang lainnya, melainkan acak di bulan-bulan tertentu. Nilai tertinggi tersebut sering kali ditemui pada bulan November yang mana memiliki frekuensi kemunculan sebanyak dua kali yaitu di tahun 2010 dan 2016. Adapun bulan yang kerap kali didapati pada posisi nilai trading volume activity yang terendah yakni bulan Desember, dimana frekuensi kemunculannya sebanyak tiga kali berada pada posisi nilai terendah yaitu di tahun 2013, 2014 dan 2016 


\section{b. Uji Normalitas Data}

Tabel 6. Hasil Uji Normalitas Trading Volume Activity

Tests of Normality

\begin{tabular}{|l|r|r|r|r|r|r|}
\hline \multirow{2}{*}{} & \multicolumn{3}{|c|}{ Kolmogorov-Smirnov $^{\mathrm{a}}$} & \multicolumn{3}{c|}{ Shapiro-Wilk } \\
\cline { 2 - 7 } & Statistic & \multicolumn{1}{c|}{ Df } & \multicolumn{1}{c|}{ Sig. } & Statistic & \multicolumn{1}{c|}{ Df } & \multicolumn{1}{c|}{ Sig. } \\
\hline Januari_TVA & .351 & 20 & .000 & .491 & 20 & .000 \\
Sebelasbulan_TVA & .385 & 20 & .000 & .492 & 20 & .000 \\
\hline
\end{tabular}

a. Lilliefors Significance Correction

Sumber: data sekunder output SPSS

Berdasarkan hasil di atas terlihat bahwa nilai signifikan pada tabel KolmogrovSimirnov untuk trading volume activity Januari dan Sebelas bulan lainnya adalah 0.000, yang mana lebih kecil dari 0.05 , dengan kata lain data persebaran rata-rata trading volume activity tidak berdistribusi normal. Karena data persebarannya tidak normal maka uji paired sample t-test tidak dapat digunakan, namun terdapat alternatif lain untuk pengujiannya yaitu analisis statistik non parametrik yang dalam hal ini menggunakan Wilcoxon sign test.

\section{c. Uji Hipotesis (Wilcoxon sign test)}

\section{Tabel 7. Hasil Uji Wilcoxon}

Test Statistics

\begin{tabular}{|c|c|c|c|c|c|c|c|}
\hline & $\begin{array}{c}\text { tva_Sebelas } \\
\text { bulanlainny } \\
\text { a10 - } \\
\text { tva_Januari1 } \\
0\end{array}$ & $\begin{array}{c}\text { tva_Sebelas } \\
\text { bulanlainny } \\
\text { a11 - } \\
\text { tva_Januari1 } \\
1\end{array}$ & $\begin{array}{c}\text { tva_Sebelas } \\
\text { bulanlainny } \\
\text { a12 - } \\
\text { tva_Januari1 } \\
2\end{array}$ & $\begin{array}{c}\text { tva_Sebelas } \\
\text { bulanlainny } \\
\text { a13 - } \\
\text { tva_Januari1 } \\
3\end{array}$ & $\begin{array}{c}\text { tva_Sebelas } \\
\text { bulanlainny } \\
\text { a14 - } \\
\text { tva_Januari1 } \\
4\end{array}$ & $\begin{array}{c}\text { tva_Sebelas } \\
\text { bulanlainny } \\
\text { a } 15 \text { - } \\
\text { tva_Januari1 } \\
5\end{array}$ & $\begin{array}{c}\text { tva_Sebelas } \\
\text { bulanlainny } \\
\text { a16- } \\
\text { tva_Januaril } \\
6\end{array}$ \\
\hline Z & $-2.315^{\mathrm{a}}$ & $-3.696^{b}$ & $-1.755^{a}$ & $-.784^{\mathrm{a}}$ & $-1.979^{b}$ & $-.224^{\mathrm{a}}$ & $-3.136^{\mathrm{a}}$ \\
\hline $\begin{array}{l}\text { Asymp. } \\
\text { Sig. (2- } \\
\text { tailed) }\end{array}$ & .021 & .000 & .079 & .433 & .048 & .823 & .002 \\
\hline
\end{tabular}

a. Based on negative ranks.

b. Based on positive ranks.

c. Wilcoxon Signed Ranks Test

Sumber: data sekunder output SPSS

Berdasarkan hasil uji Wilcoxon terlihat hasil signifikansi yang berbeda, pada tahun 2010, 2011, 2014 dan 2016 nilai (Asymp. Sig. 2 tailed) yang diperoleh berturutturut 0.021 dengan $Z$ skor $-2.315,0.000$ dengan $Z$ skor -3.696, 0.048 dengn $Z$ skor 1.979 dan 0.002 dengan $Z$ skor -3.136 yang berarti $P$ value $<0.05$. Namu, pada tahun 2012, 2013 dan 2015 memiliki nilai (Asymp. Sig. 2 tailed) secara berturut-turut sebesar 0.079 dengan $\mathrm{Z}$ skor $-1.755,0.433$ dengan $\mathrm{Z}$ skor -0.784 , terakhir 0.823 dengan $\mathrm{Z}$ skor 0.224 , yang berarti $P$ value $>0.05$. Sehingga kesimpulan yang dapat diambil untuk bagian ini adalah terdapat perbedaan signifikan dan tidak signifikan pada beberapa tahun dilihat dari sisi trading volume activity antara Januari dan sebelas bulan lainnya pada perusahaan LQ45 di Bursa Efek Indonesia. 


\section{PEMBAHASAN}

Tidak terdapatnya fenomena ini kemungkinan disebabkan karena adanya perbedaan kebiasaan pada akhir tahun di Indonesia yang tidak terlalu disambut secara besar-besaran serta mulai berkembangnya terknologi informasi yang mampu dijangkau oleh berbagai kalangan termasuk oleh para investor. Berbicara mengenai informasi, anomali pasar modal seperti January effect terjadi karena adanya sebuah pola atau pergerakan return yang tak lagi acak melainkan terstruktur pada waktu-waktu tertentu, hal tersebut berkaitan dengan teori pasar modal yang efisien dalam bentuk lemah (weak form). Pasar dikatakan efisien dalam bentuk lemah jika harga-harga dari sekuritas mencerminkan secara penuh informasi masal lalu, informasi masa lalu ini merupakan sebuah informasi yang telah terjadi seperti data historis harga saham. Efisiensi bentuk lemah ini berkaitan dengan teori langkah acak (random walk theory) yang menyatakan bahwa data masa lalu tidak memiliki hubungan dengan nilai pada waktu sekarang. Sehingga para investor tidak dapat menggunakan informasi masa lalu untuk memiliki peluang memperoleh abnormal return.

\section{KESIMPULAN}

Berdasarkan hasil penelitian dan pembahasan yang telah dilakukan pada bab sebelumnya, maka dapat ditarik kesimpulan bahwa terdapat perbedaan signifikan dan tidak signifikan dilihat sisi abnormal return dan trading volume activity antara bulan Januari dengan sebelas bulan lainnya pada perusahaan LQ45 dan fenomena January effect tidak terjadi selama periode penelitian 2010-2016.

Meskipun terdapat beberapa tahun tertentu dengan nilai signifikansi dibawah 0.05 yang berarti terdapat beda abnormal return dan trading volume activity antara Januari dengan sebelas bulan lainnya tidak berarti fenomena January effect tersebut terjadi, karena pada table abnormal return (tabel 2) dan trading volume activity (tabel 5) tidak menunjukkan nilai dari bulan Januari berada pada posisi tertinggi setiap tahunnya jika dibandingkan dengn sebelas bulan lainnya kecuali di tahun 2011 pada sisi trading volume activity. Sehingga dari hasil tersebut membuktikan bahwa anomali atau fenomena January effect tidak terjadi pada perusahaan yang terdaftar dalam Indeks LQ45 yang ditinjau dari abnormal return dan trading volume activity di Bursa Efek Indonesia periode 2010-2016.

\section{DAFTAR PUSTAKA}

Andreas, dan Ria D. 2011. January Effect pada Perusahaan LQ-45 Bursa Efek Indonesia 2003-2008. Jurnal Ekonomi. 19(3). p.11 -21.

Astuti, D. dan Herman L. 2007. Pengujian January Effect di Bursa Efek Jakarta (studi kasus LQ-45 di BEJ). Skripsi Jurusan Akuntansi. STIE Nusa Megar Kencana.

Bodie, Z., Alex K., dan Alan J.M. 2011. Investment and Portofolio Management. Global Edition. Singapore: Mc Graw-Hill Irwin.

Fama E.S. 1970. Efficient Capital Market. Areview of Theory and Empirical Work. Journal of Finance, Vol 25. p383-417 
Fitriani, I., dan Maria, M.R. 2013. Analisis January Effect pada Kelompok Saham Indeks LQ-45 di Bursa Efek Indoneia Tahun 2009-2011. E-Jurnal Akutansi Universitass Udayana. Bali. ISSN: 2302-8556.p106-109

Ghozali, I. 2006. Aplikasi Analisis Multivariate dengan Program SPSS. Edisi Ke 4. Semarang: Badan Penerbit Universitas Diponegoro.

Hartono, J. 2008. Teori Portofolio dan Analisis Investasi. Yogyakarta: Yogyakarta BPFE

Hartono, J. 2010. Teori Portofolio dan Analisis Investasi. Yogyakarta: Yogyakarta BPFE

Hartono, J. 2016. Teori Portofolio dan Analisis Investasi. Yogyakarta: Yogyakarta BEFE

Husnan, S. 2009. Dasar-dasar Teori Portofolio dan Analisis Sekurita. Edisi Keempat. Yogyakarta: Penerbit UPP STIM YKPN.

Indonesian Stock Exchange: Ringkasan Saham. http://idx.co.id/data-pasar/ringkasanperdagangan/ringkasan-saham/. Diakses pada tanggal 28 Mei tahun 2018

Marliasari, K. 2014. Pengaruh January Effect dan Rogalski Effect Terhadap Abnormal Return Saham dan Trading Volume Activity (Studi pada Perusahaan LQ 45 yang Terdaftar di Bursa Efek Indonesia). Skripsi. Malang.Fakultas Ekonomi dan Bisnis Universitas Brawijaya.

Octavianti P. B, 2009. Analisis Fenomena January Effect Terhadap Return Pasar Di Bursa Efek Indonesia Studi Pada Indeks Sektoral Di Bursa Efek Indonesia Periode 2001-2008. Skripsi. Surakarta. Universitas Sebelas Maret.

Pertiwi, P.C. dan Isynuwardhana, D. 2014. January Effect Pada Perusahaan LQ 45 Di Bursa Efek Indonesia Periode 2009-2013. skripsi. Bandung. Fakultas Ekonomi.Universitas Telkom.

Rahayu, Linda. 2016. Analisis Pengujian Fenomena January Effect Pada Perusahaan LQ 45 di Bursa Efek Indonesia (BEI) Periode 2011-2015. Skripsi. Mataram. Fakultas Ekonomi dan Bisnis Universitas Mataram.

Ritter J. dan N. Chopra. 1989. Portofolio Rebalancing and the Turn of the Year Effect. Journal of Finance. Vol. 44. p149-166.

RSM Indonesia dan Indonesia Stock Exchange. 2015. Indonesian Capital Market Directory 2015. Edisi ke-26. Jakarta: ECFIN.

Sari, F.A. dan Sisdyani, E.A. 2014. Analisis January Effect di Pasar Modal Indonesia. EJurnal Akutansi Universitas Udayana. Bali. ISSN: 2302-8556.p1-12

Sartono, A. 2001. Manajemen Keuangan Teori dan Aplikasi. Yogyakarta: BPEFYOGYAKARTA.

Sharpe W.F, Alexander G.J.dan Bailey J. V. 1995. Investment. Prantice Hall: New Jersey.

Sugiyono. 2012. Metode Penelitian Bisnis. Bandung: Alfabrta CV

Sunariyah. 2011. Pengantar Pengetahuan Pasar Modal. Edisi Keempat. Yogyakarta: UPPAMP YKPN 
Thaler, R.H. 1987. Anomalies the January Effect. Economic Perspectives. Cornell University, Ithaca. New York. Vol. 1 No. 1 p. 197-201.

Wulandari, A. 2014. Analisis Fenomena January Effect Pada Saham LQ 45 Yang Listing di Bei Periode 2009-2013. Skripsi. Fakultas Ekonomi Universitas Negeri Padang. Padang.

Dunia Invetasi. Data Bursa Efek Indonesia. Diakses pada situs http://www.duniainvestasi.com/. Web.15 Nov. 2017 